\title{
Congenital Granular Cell Epulis
}

\author{
Ryo Sasaki, DDS, $\mathrm{PhD}^{*+}$; Toshihiro Okamoto, DDS, $\mathrm{PhD}^{*}$; Yorikatsu Watanabe, MD, PhD+; Chie Kagawa, DDS*; \\ Tomohiro Ando, DDS, PhD*
}

Sir,

1-day-old Japanese baby girl was consulted to oral and maxillofacial surgeon. An approximately $15 \times 15 \mathrm{~mm}$ pedunculated mass with a healthy color attached to maxillary alveolar ridge was observed in the right maxillary deciduous canine or first molar region (Fig. 1). The baby was born by normal delivery at 40 weeks and 2 days' gestation. Birth weight was $3,486 \mathrm{~kg}$. She had no congenital malformation. The mother of the baby was a 33-year-old Japanese; she had asthma. There were no medications, alcohol, or tobacco used. Both the father and older brother had no medical history. A clinical diagnosis of congenital epulis was made. She showed no feeding problem. Four months after, she became $60 \mathrm{~cm}$ tall with a body weight of $6.5 \mathrm{~kg}$, and the patient was scheduled for surgical excision. The surgical excision was performed under general anesthesia without complications. Histopathological analysis of the mass showed proliferation of large cells with granular cytoplasm under the squamous epithelium (Fig. 2). Immunohistological analysis revealed S-100 negative, weakly positive for CD68 (KP-1), and finally diagnosed with congenital granular cell epulis. No postoperative recurrence was recognized. Congenital granular cell epulis is a rare benign tumor arising from alveolar ridges of newborns and composed of sheet of cells with cytoplasmic granules. There is no reactivity with S-100 protein. Females are affected 10 times more often than males. It occurs twice as often in maxilla as in the mandible, usually presenting as solitary, somewhat pedunculated fibroma-like lesion attached to the alveolar ridge near the midline. The size varies from a few millimeters up to several centimeters. ${ }^{1}$ In this case, the authors have planned to resect the mass under general anesthesia at a body weight that allowed general anesthesia to be performed more safely until before mandibular deciduous central incisor eruption (before 6 months old) concerning the trauma caused by baby teeth, because (1) she showed no feeding problem

From the *Department of Oral and Maxillofacial Surgery, Tokyo Women's Medical University, School of Medicine, Tokyo, Japan; $\dagger$ Toho Women's Clinic, Tokyo, Japan; and $\ddagger$ Department of Plastic and Reconstructive Surgery, Tokyo Metropolitan Police Hospital, Tokyo, Japan.

Copyright $@ 2018$ The Authors. Published by Wolters Kluwer Health, Inc. on behalf of The American Society of Plastic Surgeons. This is an open-access article distributed under the terms of the Creative Commons Attribution-Non Commercial-No Derivatives License 4.0 (CCBY-NC-ND), where it is permissible to download and share the work provided it is properly cited. The work cannot be changed in any way or used commercially without permission from the journal. Plast Reconstr Surg Glob Open 2018;6:e1989; doi:10.1097/

GOX.0000000000001989; Published online 1 November 2018. and (2) a spontaneous regression of congenital epulis has been reported. ${ }^{2}$ Eventually, the surgical excision was performed at 4 months, although interestingly the mass was shrunk from $15 \times 15 \mathrm{~mm}$ to $5 \times 8 \mathrm{~mm}$. The histogenesis is still unknown. ${ }^{1-5}$ In this case, the lesion showed weakly positive for CD68, which is a rare histopathological finding. However, some cases with CD68 positive are reported..$^{3,4}$ Vered et al. ${ }^{5}$ have reported that immunohistological analysis using the broad panel of antibodies that characterize different tissues confirms no particular cell type for the histogenetic origin of congenital granular cell epulis. However, the lesion will be of non-neoplastic nature because the clinical course is characterized by

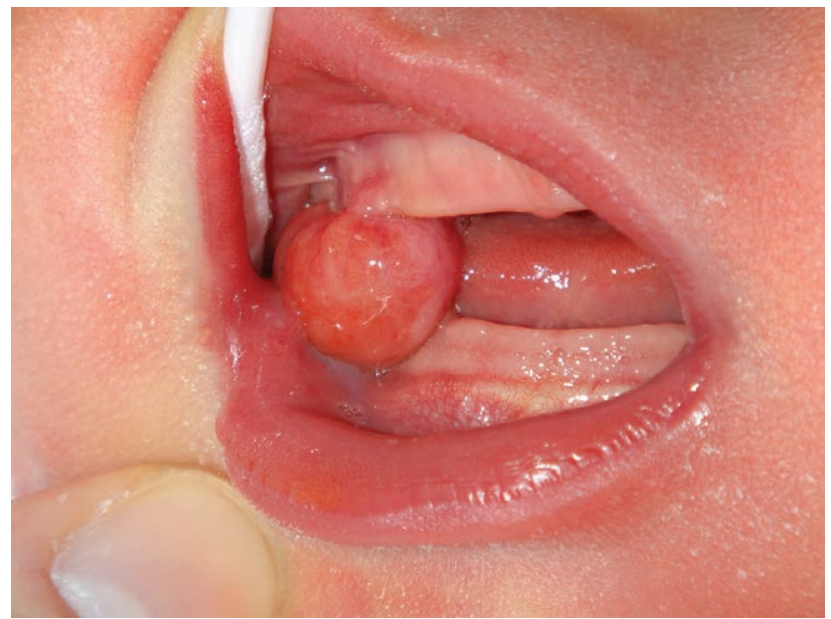

Fig. 1. Intraoral photograph in 1-day-old baby girl. An approximately $15 \times 15 \mathrm{~mm}$ pedunculated mass with a healthy color attached to maxillary alveolar ridge was observed in the right maxillary deciduous canine or first molar region.

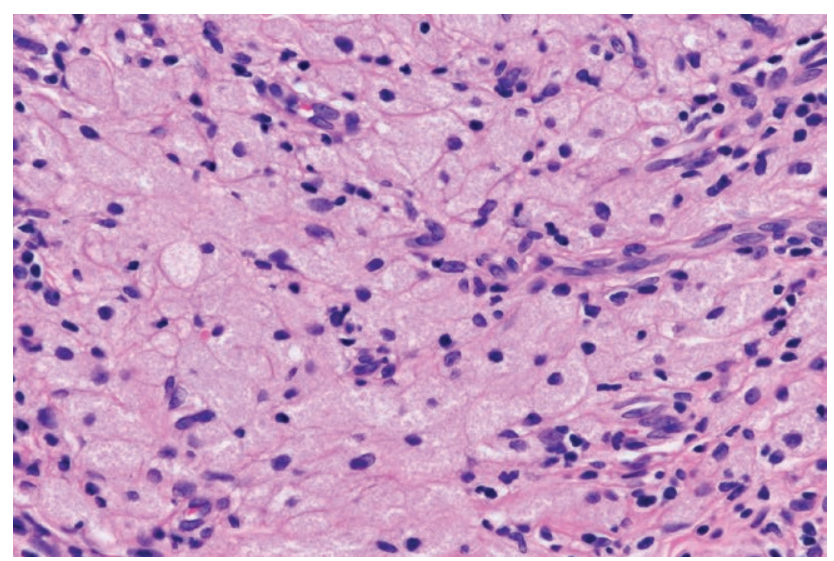

Fig. 2. Hematoxylin-eosin staining of the mass. Proliferation of large cells with cytoplasmic granules under the squamous epithelium was observed (magnification of $\times 400$ ). 
(1) no growth after birth; (2) regression during the first year of life; and (3) no recurrence despite an incomplete excision. ${ }^{5}$

Ryo Sasaki, DDS, PhD

Department of Oral \& Maxillofacial Surgery

Tokyo Women's Medical University

School of Medicine

8-1 Kawada-cho, Shinjuku-ku

Tokyo 162-8666, Japan

E-mail: sasaki.ryo@twmu.ac.jp

\section{DISCLOSURE:}

The authors have no financial interest to declare in relation to the content of this article. The Article Processing Charge was paid for by the Department of Oral $\mathcal{E}^{\circ}$ Maxillofacial Surgery, Tokyo Women's Medical University.

\section{ACKNOWLEDGMENTS}

The authors thank Dr. Naoyuki Matsumoto (Department of Pathology, Tsurumi University, School of Dental Medicine) for pathological finding, and Drs. Miki and Hisami Matsumine and all the staff at Toho Women's Clinic for their kind support and assistance.

\section{REFERENCES}

1. Allen CM, Bullerdiek J, Ro JY. Congenital granular cell epulis. In: El-Naggar AK, Chan JKC, Grandis JR, Takata T, Slootweg PJ, eds. WHO Classification of Head and Neck Tumours. 4th ed. Lyon, France: IARC Press; 2017:119.

2. Jenkins HR, Hill CM. Spontaneous regression of congenital epulis of the newborn. Arch Dis Child. 1989;64:145-147.

3. Kaiserling E, Ruck P, Xiao JC. Congenital epulis and granular cell tumor: a histologic and immunohistochemical study. Oral Surg Oral Med Oral Pathol Oral Radiol Endod. 1995;80:687-697.

4. Aresdahl A, Lindell B, Dukic M, et al. Congenital granular cell epulis-a case report. Oral Maxillofaci Surg Case. 2015;1:8-11.

5. Vered M, Dobriyan A, Buchner A. Congenital granular cell epulis presents an immunohistochemical profile that distinguishes it from the granular cell tumor of the adult. Virchows Arch. 2009;454:303-310. 